\title{
Value of substitute consent and autonomy of research participants in Regulation (EU) No $536 / 2014$
}

\author{
Rafał Patryn ${ }^{1, A-D, F} \oplus$, Anna Zagaja ${ }^{1, C, E-F} \oplus$ \\ ${ }^{1}$ Chair and Department of Humanities and Social Medicine, Medical University, Lublin, Poland \\ A - Research concept and design, B - Collection and/or assembly of data, C - Data analysis and interpretation, \\ $D$ - Writing the article, E - Critical revision of the article, F - Final approval of article
}

Patryn R, Zagaja A. Value of substitute consent and autonomy of research participants in Regulation (EU) No 536/2014. J Pre-Clin Clin Res. 2020; 14(4): 156-159. doi: 10.26444/jpccr/131221

\begin{abstract}
Introduction and Objective. For years the concept of informed consent has been gaining strength as an expression of patient and research participant's autonomy. The interpreted Regulations allows for obtaining a substitute consent from that person's legally designated representative which, de facto, is the decision of an authorized entity to include the participant in the study presuming that he/she would agree. The inability to consent in a specific situation and allowing for substitute consent from a different entity (a legally designated representative) is permission to participate in the proposed form of clinical trial. Through the introduced solution, the autonomy of the participant who, for various reasons, cannot consent to participate in clinical trials has been limited. The aim of the study was to analyze the concept of substitute consent in a research setting.

Brief description of the state of knowledge. The legal obligation to obtain consent originates from the early 20 th century. This concept has evolved over the years and broadened in scope to increase the significance of patient autonomy. The analyzed Regulation indicates that the concept of informed consent has been redefined in the clinical research setting to incorporate those who lack the possibility to self-decide. The directive introduces the concept of substitute consent, which is an innovative solution that can affect current research protocols.

Conclusion. Traditional requirements for informed consent have been omitted (in this redefined Act), which is an innovative legislative solution that can facilitate research.
\end{abstract}

\section{Key words}

law, clinical trials, informed consent, research participants

\section{INTRODUCTION AND OBJECTIVE}

One of the main challenges of this Regulation is to overcome the lack of harmonization of procedures related to clinical trials conducted within and between different European Union Member States. Initiatives contained in the Regulation concern research registration in the European database, and preparation of relevant documents related to the process of providing information and obtaining consent from potential research participants. The Regulation additionally aims to merge various rules concerning informed consent in emergency situations $\mathrm{n}$ orders to bring benefits to both participants of such research and the researchers. This aspect is becoming increasingly important considering the growing number of multi-centre and international studies. The new Regulation allows for conducting trials in emergency situations without prior consent, naturally under several conditions [1]. This is an innovative solution, all the more so because recent decades have abounded in the development of possibilities of conduct related to strict compliance with research participants' subjectivity and autonomy $[2,3,4]$. This compliance manifests itself in the number of types of consents used in the medical setting (Tab. 1). The aim of the proposed review article was to bring closer the introduced Regulation and to turn attention towards the possibility

Address for correspondence: Anna Zagaja, Chair and Department of Humanities and Social Medicine, Medical University, Lublin, Poland

email: anna.zagaja@umlub.pl

Received: 29.10.2020; accepted: 03.12.2020; first published: 21.12.2020 of redefining informed consent and obtaining it through simplified means (substitute consent).

\section{STATE OF KNOWLEDGE}

On analyzing the content of the Regulation on clinical trials of medicinal products for human use, new consentrelated concepts emerge $[5,6]$ which apply to participants in emergency situations and those incapacitated. The process of medical research, apart from meeting a number of specific conditions of a specialist and technological nature, also requires knowledge of the legal principles related to conducting clinical trials. [7, 8, 9, 10] These principles focus mainly on the participation and qualification of clinical trial participants. [6] The proportionality of acceptable and possible risk-to-benefit ratio is currently determined by a declaration of will of the research participant, i.e. constructs of informed consent $[11,12,13,14]$.

The necessity to obtain consent from research participants had already been noted and underlined at the end of the 19 th century. One of the first legal regulations springing from lack of consent was a decree specifying requirements of obtaining consent issued following a syphilis experiment conducted by Professor Neisser [15]. Unethical research conducted in the $20^{\text {th }}$ century forced the adoption of the Nuremberg Code which, for the first time, defined ten rules for the admissibility of experiments on humans. Another important Act is the Helsinki Declaration of the World 
Table 1. Chosen types of consent and their characteristics

\begin{tabular}{|c|c|c|c|c|c|}
\hline FEATURES TYPE & Presumed & Blanket & Dynamic & Informed & Substitute \\
\hline Form of consent & Conclusive & $\begin{array}{l}\text { Written/ } \\
\text { Oral/ Conclusive }\end{array}$ & Written / Conclusive & Written & Written \\
\hline $\begin{array}{l}\text { Time for making a } \\
\text { decision }\end{array}$ & - & Short & Short & $\begin{array}{l}\text { Individually } \\
\text { determined }\end{array}$ & Short \\
\hline $\begin{array}{l}\text { Entity authorized to } \\
\text { express consent }\end{array}$ & $\begin{array}{l}\text { In person -necessity } \\
\text { to express refusal }\end{array}$ & $\begin{array}{l}\text { Legal representative/ } \\
\text { In person }\end{array}$ & $\begin{array}{l}\text { Legal representative/ } \\
\text { In person }\end{array}$ & $\begin{array}{l}\text { Legal representative/ } \\
\text { In person }\end{array}$ & $\begin{array}{l}\text { Legal representative /entity indicated in } \\
\text { substitution }\end{array}$ \\
\hline Information & - & - & General information & Full information & $\begin{array}{l}\text { Information determined in its scope by the } \\
\text { research organizer or other authorized entity }\end{array}$ \\
\hline Application & Transplantation & Medical aid & Scientific research & Medical aid/ research & Scientific research \\
\hline
\end{tabular}

Medical Association, which defines the ethical principles for conducting research involving humans.[16, 17] According to the Declaration, the physician is required, among others, to obtain the research participant's voluntary consent. In the case where the person is incapable of self-deciding, informed consent should be obtained from the legal representative of the research participant. Article 5 of the Convention for the Protection of Human Rights and Human Dignity in the Application of Biology and Medicine, also specifies the elementary principle of consent (informed and free) of the research participant of any interference. Currently, participants' consent is a necessary condition for conducting research, as well as for any medical interference. Article 5 of the Oviedo Convention on Human Rights and Biomedicine also determines the basic principles of consent of the research participant (information and voluntariness [18].

Pursuant to the provisions of the definition contained in the discussed Regulation - informed consent signifies a subject's

free and voluntary expression of his or her willingness to participate in a particular clinical trial, after having been informed of all aspects of the clinical trial that are relevant to the subject's decision to participate or, in case of minors and of incapacitated subjects, an authorisation or agreement from their legally designated representative to include them in the clinical trial [19].

The regulation, which is a legislative novelty, introduces the categorization of informed consent for participants who are free to express it, and for those who are not fully able or entitled to do so, i.e. in case of emergencies related to loss of consciousness, or those incapacitated $[14,19]$. In this situation, a specific legally designated entity is entitled to provide consent, which in the nomenclature of the Regulation is also termed 'informed'.

When conducting clinical trials, some of the patients may (and even for their own benefit) be included in the studies when their current state of health precludes the possibility of providing informed consent. In such a situation, it is impossible to fulfill the basic condition for participation in a clinical trial [20]. To facilitate participation, the Regulation sets out the premise for omitting the participant's consent in strictly defined situations $[21,22]$. This applies to the impossibility of articulating an opinion, e.g. by patients who are unconscious, incapable of expressing their will, and patients who are in emergency situations identified as being life threatening that require immediate medical attention. Additionally, scientific knowledge assumes that the participation in a clinical trial of a participant who cannot provide consent can result in significant benefits in the form of: health improvement, $r$ alleviation of suffering, or even a cure [23].

Article 3 of the Charter of Fundamental Rights of the European Union contains a provision on obtaining informed consent from a person subjected to medical interventions, [24] according to which informed consent requires a free and voluntary declaration of the patient's (participant's) will to undergo the proposed medical intervention (in this context for clinical trials) [25]. Therefore, the state of participants who are unable to provide consent precludes obtaining informed consent in the traditional manner. However, when it is beneficial to conduct a trial with this category of participants and scientific information of similar value cannot be obtained through studies involving participants who are able to consent, such research would be of great value. The new solution introduces a specific procedure of substitute consent by obtaining it from the participant's legal representative. In this case, it is impossible to speak about the informed consent of the research participant, but rather about the decision by an authorized entity's to include such a participant in the research - presuming that the participant would agree to it. Therefore, a definite novelty is that the specificity of such situations allows for obtaining consent from a person's legal representative. Information on the details of a clinical trial is provided to the legally designated representative of such a person, or himself, if he/she is able to understand them.

A legally designated entity should be understood as a statutory or legal representative who acquires the possibility to issue consent in substitution under appropriate procedures. The Regulation specifies that the method of designating such a representative is left to the Member States. [19] A legally designated representative may, in accordance with the Regulation, be

a natural or legal person, authority or body which, according to the law of the Member State concerned, is empowered to give informed consent on behalf of a subject who is an incapacitated subject or a minor.

In the Polish legal system, this rule will apply to a legal representative of the incapacitated person (i.e. statutory representative), a guardian of a person partially incapacitated, or the guardianship court [24]. Due to the significance of such a solution, granting consent by an authorized entity instead of a potential research participant is specified in provisions that describe such proceedings. The process 
of obtaining consent in situations where the research participant is unable to grant one should be preceded by information on the conducted clinical trial to the legal representative. The obligation to inform the subject or his legal representative is specified in Article 29 of the Regulation [19] which determines the rules and scope of obtaining informed consent from the subject or his/her legally designated representative. In order to obtain such consent, the following information should be provided either to the subject or his/her representative:

a. the nature, objectives, benefits, implications, risks and

inconveniences of the trial;

b. expected duration of the subject's participation;

c. possible treatment alternatives;

d. consequences of discontinuing the trial;

e. rights of research participants [19].

The information provided should be comprehensive, concise, clear, relevant and understandable to a person without professional knowledge, and needs to be provided prior to a planned clinical trial by a member of the research team. There also needs to be information provided on the compensation system, research number and the availability of research results [19]. The participant or his/her legal representative should also be provided with an appropriate (sufficient) amount of time to consider the decision. Afterwards, consent is to be obtained in writing from the subject or signed by the legally designated representative. Clinical trial in case of subjects unable to express consent or participants who did not express consent prior to the onset of their incapacity (Art. 31) may be conducted only when the conditions set in Article 28 are met, and when consent is obtained from the legally designated representative of such a person [19]. The researcher should also respect the subject's rights regarding his/her refusal to participate (or withdrawal from) the clinical trial. The subjects and their legal representatives are not to be offered any material incentives (financial or other), except for the reimbursement of expenses incurred for loss of earnings during the time of research [19]. The mechanism bypassing the participant's informed consent and the use of substitute consent may be applicable in clinical trials with a low degree of intervention. What should be emphasized and what constitutes another novelty is the possibility of obtaining consent via electronic means (i.e. video) in the presence of an impartial witness in a situation where the subject is able to understand the information but unable to sign proper documentation (a document confirming such consent is then to be signed by the witness). Afterwards, the participant or the legal representative receives a document (or registered material) demonstrating and confirming consent to clinical trial [19].

\section{CONCLUSION}

Consent, which here is de facto a substitute consent, constitutes a departure from the traditionally understood informed consent [26]. The concept, bypassing consent in the case of specific groups of patients or specific conditions in which patients find themselves, provides an opportunity to formulate questions on the limits of autonomy in the decisionmaking process, and ultimately its value. The Regulation clearly indicates that informed consent is unnecessary in clinical trials among particular categories of patients; such a view is also represented more extensively in other publications $[27,28]$. The process of ceding the possibility of expressing consent to a different entity (i.e. a legally designated representative) is to bring direct and measurable benefits for research participants in the health care sphere. Substitute consent to participate in a clinical trial introduced in the Regulation may cause subjects to question such a consent model after regaining consciousness and denying consent to such proceedings. Subject's argumentation may be based on the impossibility of prior firm articulation of such a decision. This, in turn, may initiate a dangerous situation in the participant-research relationship, where, in the absence of consent, and in the name of expected and foreseen research benefits, the participant's autonomy expressed by his/her consent is not taken into account. As a consequence, this may lead to claims for damages in the event of proving the original stance of disagreement to conduct a clinical trial and simultaneously to such a procedure. It may also cause litigation in the case of a trial to obtain damages. The process of obtaining such consent may also raise numerous doubts in its interpretation, and additionally constitute a certain real threat associated with possible abuses, which would involve making decisions for a participant or even for participants in the name of conducting specific research. This Regulation gives a great deal of discretion to entities that are entitled to express substitute consent, and may cause various ethical dilemmas.

\section{Declaration}

The authors declare they have no conflict of interest nor did they receive any funding for the study.

\section{REFERENCES}

1. Kompanje EJO, Maas AIRm Menon DK, Kesecioglu J, Medical research in emergency research in the European Union member states: tensions between theory and practice. Intensive Care Med. 2014; 40: 496-503.

2. Millum J, Beecroft B, Hardcastle TC, et al Emergency care research ethics in low-income and middle-income countries. BMJ Global Health. 2019; 4: e001260.

3. El-Menyar A, Asim M, Latifi R, et al. Research in Emergency and Critical Care Settings: Debates, Obstacles and Solutions. Sci Eng Ethics. 2016: 22; 1605-1626. https://doi.org/10.1007/s11948-015-9730-5

4. Levine AC, Barry AM, Agrawal P, Duber HC, Chang MP, Mackey JM, Hansoti B, Global Health and Emergency Care: Overcoming Clinical Research Barriers. SAEM. 2017; 24, 4: 484-493.

5. Hurst SA, Vulnerability in research and health care; describing the elephant in the room? Bioethics. 2008; 22: 191-202.

6. Tenti E, Simonetti G, Bochicchio MT, Martinelli G, Main changes in European Clinical Trials Regulation (No 536/2014). Contemporary Clinical Trials Communications. 2018; 11; 99-101.

7. Mende A, Frech M, Riedel C. Principles of the EU Clinical Trials Regulation No 536/2014: What will change? Bundesgesundheitsblatt, Gesundheitsforschung, Gesundheitsschutz. 2017; 60(8): 795-803.

8. Mentzelopoulos SD, Mantzanas M, van Belle G, Nichol G, Evolution of European Union legislation on emergency research. Resuscitation. 2015; 91: 84-91.

9. Saito H, Gill CJ How Frequently Do the Results from Completed US Clinical Trials Enter the Public Domain? - A Statistical Analysis of the ClinicalTrials.gov Database. PLOS ONE. 2014: 9(7): e101826. https:// doi.org/10.1371/journal.pone.0101826

10. Gallin JI, A historical perspectives on clinical research. In: Gallin JI, Ognibene F, editors. Principles and practice of clinical research. Burlington, MA: Elsevier; 2008.

11. Giannuzzi V, Altavilla A, Ruggieri L, et al. Clinical Trial Application in Europe: What Will Change with the New Regulation? Sci Eng Ethics. 2016; $22: 451$. 
12. Rebers S, Aaronson NK, Van Leeuwen FE, Schmidt KM. Exceptions to the rule of informed consent for research with an intervention. BMC Med Ethics. 2016; 6: 17: 9.

13. Petrini C. Regulation (EU) No 536/2014 on clinical trials on medicinal products for human use: an overview. Ann Ist Super Sanità. 2014; 50(4) 317-321. http://www.scielosp.org/pdf/aiss/v50n4/04.pdf

14. Farisco M, Evers K, Petrini C. Biomedical research involving patients with disorders of consciousness: ethical and legal dimensions. Ann Ist Super Sanita. 2014; 50(3): 221-8.

15. Vollmann J, Winau R. Informed consent in human experimentation before the Nurenberg code. BMJ 1996; 313(7070): 1445-1449.

16. Katz J. Informed consent--a fairy tale? Law's vision. Univ Pittsbg Law Rev. 1977; 39(2): 137-174.

17. Beauchamp TL, Informed consent: its history, meaning, and present challenges. Camb Q Healthc Ethics. 2011; 20: 515-523.

18. Grady Ch. Enduring and Emerging Challenges of Informed Consent. N Engl J Med. 2015; 372: 855-86. doi: 10.1056/NEJMra1411250

19. Rozporządzenie Parlamentu Europejskiego i Rady (UE) nr 536/2014, z dnia 16 kwietnia 2014 r. w sprawie badań klinicznych produktów leczniczych stosowanych u ludzi. [4.12.2019]. http://ec.europa. eu/health//sites/health/files/files/eudralex/vol-1/reg_2014_536/ reg_2014_536_pl.pdf

20. Savonitto S, Coppola T, Braglia P, Ciccone A. Informed consent for clinical investigation in the critically ill patient. An introduction to the regulation 536/2014/EC on clinical investigation of medicinal products for human use, repealing Directive 2001/20/EC. GItal Cardiol (Rome) 2016; 17; 326-334.

21. Rutkowska E. Nowe unijne prawo dotyczące badań klinicznych. [10.06.2020] http://www.rynekzdrowia.pl/Farmacja/Nowe-unijneprawo-dotyczace-badan-klinicznych,142818,6.html

22. Turzański P. Nowe badania kliniczne. [8.09.2020] http://biotechnologia $\mathrm{pl} / \mathrm{kwartalnik} /$ Nowe-badania-kliniczne, 88

23. Liddell K, Bion J, Chamberlain D, Druml C, Kompanje E, Lemaire F, Menon D, Vrhovac B, Wiedermann CJ. Medical research involving incapacitated adults: Implications of the EU clinical trials directive 2001/20/EC. Medical Law Review. 2006; 14(3): 367-417.

24. Karta praw podstawowych Unii Europejskiej 2012/C 326/02 [2.03.2019] http://eur-lex.europa.eu/legal-content/PL/ TXT/?uri=CELEX\%3A12012P\%2FTXT

25. Dunn LB, Nowrangi MA, Palmer BW, Jeste DV, Saks ER. Assessing decisional capacity for clinical research or treatment: a review of instruments. Am J Psychiatry. 2006; 163: 1323-34.

26. Patryn R. Zgoda na wykonanie świadczenia zdrowotnego. Rodzaje zgody, ich zakres i zastosowanie. Neurol. Prakt. 2017; 1: 68-73.

27. Dal-Ré $\mathrm{R}$, et al. Low risk pragmatic trials do not always require participants' informed consent. BMJ. 2019; 364(27): 11092. https://doi: 10.1136/bmj.11092

28. Kalkman S, et al. Series: Pragmatic trials and real world evidence: Paper 4. Informed consent. J Clin Epi. 2017; 28: 181-187. https://doi. org/10.1016/j.jclinepi.2017.03.019 